
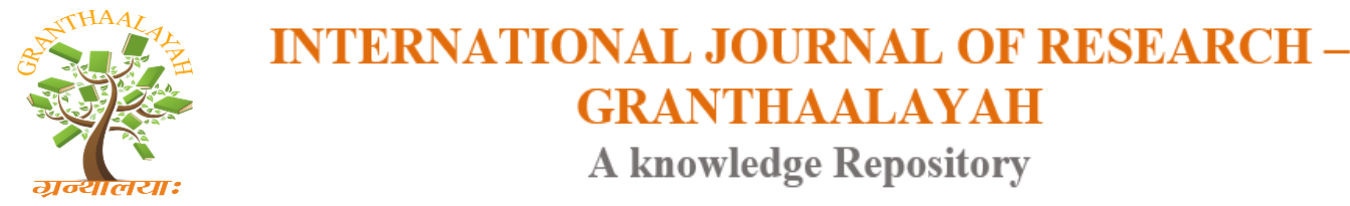

Science

\title{
FISH AS BIOCONTROL AGENT AGAINST MOSQUITOES: AN OPINION
}

\author{
Subha Ganguly *1
}

${ }^{* 1}$ Associate Professor, Department of Veterinary Microbiology, Arawali Veterinary College (Affiliated with Rajasthan University of Veterinary and Animal Sciences, Bikaner), N.H. - 52 Jaipur Road, V.P.O. Bajor, Sikar - 332001, Rajasthan, INDIA

DOI: https://doi.org/10.29121/granthaalayah.v4.i11.2016.2425

\section{ABSTRACT}

Gambusia affinis or mosquitofish play a vital role as biocontrolling agents which feed on mosquito larvae populations. These are freshwater fishes with adult females reaching an overall length of $7 \mathrm{~cm}$ and adult males attain a length of nearly $4 \mathrm{~cm}$.

\section{Keywords:}

Biocontrol, Mosquitofish, Mosquito larvae.

Cite This Article: Subha Ganguly, "FISH AS BIOCONTROL AGENT AGAINST MOSQUITOES: AN OPINION" International Journal of Research - Granthaalayah, Vol. 4, No. 11 (2016): 101-102.

\section{INTRODUCTION}

The mosquitofish is a member of the order Cyprinodontiformes and family Poeciliidae. The name suggests that its diet is mainly composed of mosquito larvae. The generic name of the fish is Gambusia and its common name is gambezi. [1]

\section{REPRODUCTION}

Reproduction in these fishes occurs by internal fertilization. Female fishes are somewhat larger in size that the male counterparts with a gravid spot at the posterior abdomen which reach sexual maturity within 21 to 28 days.[2]

\section{MORPHOLOGY}

Mosquitofish are small and dull grey in body color having a large abdomen and rounded dorsal and caudal fins and an upturned mouth and pronounced sexual dimorphism.

Mosquitofish generally feed on mosquito larvae including zooplanktons, insect larvae and detritus. Adult fish can consume hundreds of mosquito larvae daily. [3-5] 


\section{HABITAT}

Mosquitofishes are generally predominant in the shallow waters of the southern parts of Illinois and Indiana, throughout the Mississippi River and its tributary waters, to as far south as the Gulf Coast in the northeastern parts of Mexico. They can resist low dissolved oxygen concentrations, high salt concentrations and temperatures up to $42 \mathrm{oC}(108 \mathrm{oF})$ for short periods.[1,4]

\section{CONCLUSION}

The introduction of mosquitofishes in large water bodies has proved harmful to indigenous aquatic life and non-native ecosystems than to the mosquito population. Mosquitofish have aggressive attitude by which they kill or injure other small fishes.

\section{REFERENCES}

[1] Dionne, Michele (1985). Cannibalism, Food Availability, and Reproduction in the Mosquito Fish (Gambusia affinis): A Laboratory Experiment". The American Naturalist, 1985, 126: 16-23. doi:10.1086/284392. JSTOR 2461558.

[2] Kuntz, Albert. Notes on the Habits, Morphology of the Reproductive Organs, and Embryology of the Viviparous Fish Gambusia affinis. Bulletin of the United States Bureau of Fisheries. Department of Commerce, 1913, 33: 181-190.

[3] Rajkumar, R. Trophic microvilli of the belated embryos of Gambusia affinis (Baird and Girard) (Atheriniformes: Poeciliidae). Journal of the Inland Fisheries Society of India Barrackpore, 1987, 19(1): 32-36.

[4] Krumholz, Louis. Northward Acclimatization of the Western Mosquitofish, Gambusia affinis affinis. Copeia, 1944(2): 82. doi:10.2307/1438757

[5] Vinogradova, Elena Borisovna. Culex pipiens pipiens mosquitoes: taxonomy, distribution, ecology, physiology, genetic, applied importance and control. Pensoft Publishers, 2000, ISBN 978-954-642-103-6. 